\title{
Clinical analysis of 42 cases of EBV-positive mature T/NK-cell neoplasms
}

\author{
HAIYAN YANG, GAN FU, JIA LIU, ZHENZHEN DA, XIAOYE CHENG, \\ CONG CHEN, YAN LI, BIN FU and XIAOLIN LI
}

Department of Hematology, Xiangya Hospital of Central South University, Changsha, Hunan 410008, P.R. China

Received December 15, 2015; Accepted March 31, 2017

DOI: $10.3892 /$ etm.2017.4531

\begin{abstract}
The pathogenesis of Epstein-Barr virus-positive $\left(\mathrm{EBV}^{+}\right)$mature $\mathrm{T}$-cell and natural killer (NK)-cell neoplasms is challenging to understand. The clinical features are diverse, with no typical manifestation. Therefore, it is important to analyze the association of the clinical characteristics and prognoses of patients with various factors associated with $\mathrm{EBV}^{+} \mathrm{T} / \mathrm{NK}$-cell neoplasms, particularly extranodal NK/T cell lymphoma, systemic $\mathrm{EBV}^{+} \mathrm{T} / \mathrm{NK}$ cell lymphoproliferative disorders, aggressive $\mathrm{NK}$ cell leukemia and $\mathrm{EBV}^{+}$peripheral T-cell lymphoma. Therefore, 42 cases of $\mathrm{EBV}^{+} \mathrm{T} / \mathrm{NK}$-cell neoplasms with information on age, gender, fever, LDH level, complete blood count (CBC) and immunophenotype (CD5/CD20) were retrospectively analyzed to examine the clinical features, prognoses and related factors. It was found that patients $\leq 60$ years old accounted for $86 \%$ of cases. The frequency of stage III/IV disease was higher in groups with pancytopenia $(\mathrm{P}=0.005)$, high LDH level $(\mathrm{P}=0.020)$, CD5-expression status $(\mathrm{P}=0.031)$ and fever $(\mathrm{P}=0.024)$. There were significant differences in the mean International Prognostic Index (IPI) scores according to the presence or absence of fever $(\mathrm{P}=0.022)$, elevated or normal lactose dehydrogenase (LDH) levels $(\mathrm{P}=0.001)$, and pancytopenia or normal complete blood count $(\mathrm{CBC} ; \mathrm{P}=0.046)$. Analysis of overall survival showed that CD5 expression, CBC, IPI scores and LDH levels were factors associated with OS. CD5 expression $(\mathrm{P}=0.003)$, CBC $(\mathrm{P}=0.003)$ and IPI scores $(\mathrm{P}=0.017)$ were identified to be important risk factors on the basis of Cox regression analysis. The mean survival time was longer in the $\mathrm{CD}^{+}, \mathrm{CD} 20^{+}$and normal CBC groups, and there was no clear difference in survival time according to LDH level or fever. In summary, $\mathrm{CD} 5$ and CD20 may be prognostic factors in $\mathrm{EBV}^{+} \mathrm{T} / \mathrm{NK}$
\end{abstract}

Correspondence to: Professor Xiaolin Li or Dr Bin Fu, Department of Hematology, Xiangya Hospital of Central South University, 87 Xiangya Road, Changsha, Hunan 410008, P.R. China

E-mail: xylix1@yeah.net

E-mail: xyfubin@126.com

Key words: Epstein-Barr virus, T/natural killer cells, neoplasms, lymphoproliferative disorders lymphoid neoplasms, and $\mathrm{CBC}$ and fever are most likely to influence the IPI score and Ann Arbor stage.

\section{Introduction}

T/natural killer (NK)-cell neoplasms are rare, highly aggressive, insensitive to chemotherapy, and show poor prognosis and early relapse among lymphatic malignancies. They have an association with Epstein-Barr virus (EBV) infection, and $\mathrm{EBV}^{+} \mathrm{T} / \mathrm{NK}$-cell neoplasms are particularly prevalent among Asian and South American populations (1). T-cell and NK-cell neoplasms constitute $<10 \%$ of all non-Hodgkin lymphomas (NHLs) (2). The World Health Organization (WHO) 2008 classification of mature T-cell and NK-cell neoplasms includes peripheral T-cell lymphomas not otherwise specified (PTCL-NOS), extranodal NK/T lymphoma (ENKTL), and two newly listed EBV-positive lymphoproliferative disorders (LPDs), namely systemic EBV-T-cell lymphoproliferative disorders of childhood and hydroa-vacciniforme-like lymphoma (3).

The overlapping expression or coexpression of immunophenotypes in NK and T cells frequently confuses the diagnosis. ENKTL can be divided into two subtypes: Nasal (76.1\%) and extra-nasal (23.9\%) (4). The therapeutic effects and prognosis of nasal ENKTL (median survival time, 86.5 months) are better than those for extra-nasal ENKTL (median survival time, 8.6 months) (4). Approximately $80 \%$ of nasal ENKTL presents as a localized disease, whereas at $\geq 60 \%$ extra-nasal ENKTL is detected at an advanced stage (5). A previous study showed that the advanced disease presentation, highly aggressive clinical course and poor prognosis of extra-nasal ENKTL are analogous to aggressive NK-cell leukemia (ANKL) (6). PTCL-NOS can be classified into heterogeneous categories; EBV has been detected in $\sim 40 \%$ of PTCL-NOS cases (3). EBV-associated T/NK-LPDs are associated with several disorders and diseases, for example, chronic active EBV infection, EBV-associated hemophagocytic lymphohistiocytosis (EBV-HLH), hypersensitivity to mosquito bites, PTCL-NOS, ANKL and ENKTL (nasal type) $(7,8)$.

In the present study, EBV ${ }^{+} \mathrm{T} / \mathrm{NK}$-cell neoplasms such as ENKTL (extra-nasal), PTCL-NOS and EBV-LPDs (monoclonal) (9), were selected for investigation because they share similar clinical features and immune phenotypes, being highly invasive with poor prognosis. Nasal ENKTL was excluded 
from this study because its treatment and prognosis differ markedly from the extra-nasal ENKTL (4). The aim was to determine the clinical features, prognosis and relative risk factors, such as fever, complete blood count (CBC), lactate dehydrogenase (LDH) and immunophenotyping (CD5/CD20) of these neoplasms.

\section{Materials and methods}

Patients. A total of 42 inpatients with $\mathrm{EBV}^{+} \mathrm{T} / \mathrm{NK}$-cell neoplasms from May 2005 to July 2015 in the Department of Hematology of Xiangya Hospital of Central South University (Changsha, China) were reviewed. Patients with primary immunodeficiency, HIV infection, previous solid cancers and lymphoma were excluded. In addition, patients with acute or recent EBV infection were excluded. All included patients had immunohistochemical results for CD5/CD20 and were detected to be EBV-encoded RNA (EBER)-positive by in situ hybridization (ISH). The study was approved by the Ethics Committee of the Xiangya Hospital of Central South University.

Patient demographics and clinical characteristics. A total of 42 cases were included, 20 males and 22 females (male to female ratio, 1:1.1). The median age was 38 years (range, $15-80$ years). The involved organs included the lymph nodes, lymph organs and extranodal organs such as the skin, soft tissues, digestive tract, liver, spleen and bone marrow or multiple organs. The primary symptoms included fever, fatigue, emaciation, lymphadenectasis, hepatosplenomegaly and local damage, among which fever was the most common symptom. The staging of all diseases was performed according to the Ann Arbor (AA) staging system (Table I).

Auxiliary examinations. Computed tomography, ultrasound and positron emission tomography-computed tomography were used to scan the whole body, particularly the nasopharynx, neck, chest and abdomen, to determine the lesion area and select it for biopsy and pathological examination. When the T/NK-cell neoplasms involved the bone marrow, bone marrow aspiration and biopsy were performed for morphological, immunological, genetic and molecular biology analysis. The status of CD3, CD3e, CD5, CD56, CD79a, B-cell lymphoma (Bcl)-2, Bcl-6 and CD20 were examined on paraffin sections (fixed with $4 \%$ paraformaldehyde at $4^{\circ} \mathrm{C}$ for $24 \mathrm{~h}$ ) using primary antibodies (cat. nos. ZM-0417, TA506064, ZM-0280, ZM-0057, ZA-0293, ZM-0010 and ZM-0011, respectively; 1:1,000; Origene Technologies, Inc., Rockville, MD, USA) at $4^{\circ} \mathrm{C}$ for $24 \mathrm{~h}$. Samples were subsequently incubated goat anti-rabbit IgG (GA1014) and goat anti-mouse IgG (GA1004; both 1:4,000; both Boster Biological Technolog, Pleasanton, CA, USA) secondary antibodies at $37^{\circ} \mathrm{C}$ for $30 \mathrm{~min}$. The results were observed using a light microscope. Representative images of the analyses are shown in Fig. 1. EBER was tested by ISH in all cases as previously described (10). Other observation indexes included the CBC (Automatic Hematology Analyzer LH 780; Beckman Coulter, Inc., Brea, CA, USA) and serum LDH (Reagent Kit for LDH Test; Shanghai Zhicheng Biological Technology Co., Ltd., Shanghai China), assays which were conducted according to the manufacturer's protocol and were provided by the Clinical Laboratory of Xiangya Hospital.

Diagnosis, treatment and follow-up. The diseases were diagnosed on the basis of clinical features and auxiliary examination results, and according to the WHO classification (11) and NCCN Guidelines (12). The disease degree and prognosis were evaluated, and 3 years of follow-up were completed. Patients were classified according to their International Prognostic Index (IPI) scores from 0 to 5. IPI scores were calculated based on the following variables: A (age $\geq 60$ years old), L (elevated serum LDH level above normal), P (ECOG performance $\geq 2$ ), $S$ (AA stage $\geq 3$ ) and $E$ (extra-nodal sites $\geq 2$ ) (13). All patients received pegaspargase-containing regimens, Patients of stage III/IV received the modified SMILE protocol: Methotrexate (Pfizer Inc., New York, NY, USA) $2 \mathrm{~g} / \mathrm{m}^{2}$ on day 1, dexamethasone (Qilu Pharmaceutical Co., Ltd., Jinan, China) $40 \mathrm{mg} /$ day on days 2-4, ifosfamide (Baxter Oncology GmbH, Frankfurt, Germany) $1.5 \mathrm{~g} / \mathrm{m}^{2} /$ day on days 2-4, etoposide (Qilu Pharmaceutical Co., Ltd.) $100 \mathrm{mg} / \mathrm{m}^{2} /$ day on days 2-4 and pegaspargase (Jiangsu Hengrui Medicine Co., Ltd., Lianyungang China) 3,750 IU on days and 14 at least for 6 cycles. Patients of stage stage I/II were treated with the $\mathrm{CHOP}$ protocol combined with pegaspargase: Cyclophosphamide (Baxter Oncology $\mathrm{GmbH}$ ) $750 \mathrm{mg} / \mathrm{m}^{2}$ on day 1, adriamycin $40 \mathrm{mg} / \mathrm{m}^{2}$ on day 1 , navelbine (Laboratoires Pierre Fabre, Paris, France) $25 \mathrm{mg} / \mathrm{m}^{2}$ on day 1, prednisone $60 \mathrm{mg} / \mathrm{m}^{2} /$ day on days 1-5, pegaspargase (Tianjin Lisheng Pharmaceutical Co., Ltd., Tianjin, China) 3,750 IU on day 5 for 4 to 6 cycles $(12,14)$.

Statistical analysis. Data were analyzed using SPSS 19.0 statistical software (IBM SPSS, Armonk, NJ, USA). The $\chi^{2}$ test and Fisher's exact probability test were used to compare frequencies. One-way analysis of variance was used to test the measurement data. The rank-sum test was applied to ranked data. Overall survival (OS) and survival distributions were estimated by the Kaplan-Meier method and Cox regression. All P-values are 2-tailed, and $\mathrm{P}<0.05$ was considered to indicate a statistically significant result.

\section{Results}

Disease distribution according to age, gender and involved organs. The patients were divided into three groups according to age: $0-30$ years, $31-60$ years and $>60$ years. The patients aged $0-60$ years accounted for $86 \%$ of the total. The frequency of males and females in the three groups exhibited significant differences ( $\mathrm{P}=0.036$; Table II). The morbidity of men in the 31-60 years group was significantly higher compared with that in the other groups $(\mathrm{P}=0.029)$. Patients were predominantly $\leq 60$ years old, and in the 31-60 years group, there were more men than women. Of the 42 cases, lymph node as the only involved organ was found in $10(24 \%)$ cases, and $23(55 \%)$ cases had multi-organ involvement. The disease staging results based on the AA staging system were as follows: Stage I, $\mathrm{n}=6$; stage II, n=12; stage III, n=4; and stage IV, n=20 (Table II).

Association between AA stage and fever, $L D H, C B C$ and immunophenotyping (CD5/CD20). In the present study, 20 $(48 \%)$ cases had fever symptoms, of which 5 were stage I/II, 
Table I. Characteristics of $\mathrm{EBV}^{+}$mature NK/T-cell neoplasms.

\begin{tabular}{l} 
Characteristics \\
\hline Gender \\
Male \\
Female \\
Age (years) \\
$0-30$ \\
$31-60$ \\
$\geq 60$
\end{tabular}

No. $(\%)$

Involved organs

LD

$20(48)$

$22(52)$

17 (41)

$19(45)$

$6(14)$

$10(24)$

Extra-nodal organs

Multiple organs

23 (55)

AA stage

I/II

III/IV

18 (43)

2 (57)

B symptoms

Yes

$25(60)$

No

Diagnosis

EBV-LPDs

ENKTL

PTCL-NOS

ANKL

LGLL

EBV-PTLD

EATL

IPI scores

0-1

2-3

4

Fever

Yes

No

CBC

$\mathrm{N}$

$\mathrm{H}$

$\mathrm{P}$

LDH

High

Normal

$\mathrm{CD}^{\mathrm{a}}$

Negative

Positive

CD20

Negative

Positive

10 (24)

Prognoses

Following

Mortality

$16(38)$

8 (20)

5 (12)

$4(9.5)$

4 (9.5)

2 (5)

3 (6)

15 (36)

19 (45)

8 (19)

20 (48)

$22(52)$

18 (43)

$16(38)$

$29(69)$

$13(31)$

29 (69)

$32(76)$

10 (24)

$28(66)$
Table I. Continued.

Characteristics

No. $(\%)$

Lost

$4(10)$

${ }^{\text {aD }}$ ata was lost for one case. EBV, Epstein-Barr virus; LD, lymph node; AA stage, Ann Arbor stage; EBV-LPDs, EBV positive lymphoproliferative disorders; ENKTL, extranodal NK/T lymphoma; PTCL-NOS, peripheral T-cell lymphomas not otherwise specified; ANKL, aggressive NK cell leukemia; LGLL, large granular lymphocytic leukemia; EBV-PTLD, EBV-associated post-transplant lymphoma disease; EATL, enteropathy-associated T-cell lymphoma; IPI, International Prognostic Index; CBC, complete blood count; H, hemocytopenia; N, normal; P, pancytopenia; LDH, lactate dehydrogenase.

Table II. Numbers of males and females in the three age groups.

\begin{tabular}{lcrr}
\hline & \multicolumn{2}{c}{ Gender } & \\
\cline { 2 - 3 } Age (years) & Female & Male & P-value \\
\hline $0 \sim 30$ & 11 & 6 & 0.036 \\
$31-60$ & 6 & 13 & \\
$60+$ & 5 & 1 & \\
\hline
\end{tabular}

and 15 cases were stage III/IV. Of the remaining 22 cases, 13 were stage I/II and 9 were stage III/IV. The difference in disease stage for patients with and without fever was significant $(\mathrm{P}=0.024)$.

The 42 cases were divided into three groups based on the CBC: 8 normal, 18 hemocytopenia and 16 pancytopenia. With regard to the AA stage, 14 of the 16 pancytopenia patients were stage III/IV, while only 3 of the 8 patients with a normal CBC were stag III/IV, which was a significant difference $(\mathrm{P}=0.005)$.

The serum LDH level was elevated in 29 cases, 9 of whom were stage I/II and 20 of whom were stage III/IV. The remaining 13 cases included 9 of stage I/II and 4 of stage III/IV. The frequency of elevated LDH in stage III/IV patients was higher compared with that in stage I/II patients $(\mathrm{P}=0.020)$.

There were 10 cases positive for CD20 expression (B cell line), of which 2 cases were stage I/II and 8 cases were stage III/IV. The results revealed no significant difference in AA stage between the $\mathrm{CD}^{2} 0^{+}$and $\mathrm{CD}^{2} 0^{-}$groups $(\mathrm{P}=0.084)$. Furthermore, there were $12 \mathrm{CD}^{-}$cases, $29 \mathrm{CD}^{+}$cases and data was lost for one case. The ratio of AA stage prevalence was found to be significantly different between the $\mathrm{CD}^{+}$and CD5 $5^{-}$groups ( $\mathrm{P}=0.031$; Tables I and III).

Association of IPI scores with fever, LDH, CBC and immunophenotyping (CD5/CD20). The mean IPI scores were calculated in different groups according to the factors fever, LDH, CBC and immunophenotyping (CD5/CD20). The results demonstrated that the mean IPI scores in patients with fever $(\mathrm{P}=0.022)$, increased LDH levels $(\mathrm{P}=0.001)$ and pancytopenia $(\mathrm{P}=0.046)$ were higher compared with those in patients no fever, a normal LDH level and normal CBC, respectively. 
Table III. Statistical analysis for various factors according to IPI score and AA stage.

\begin{tabular}{|c|c|c|c|c|c|}
\hline \multirow[b]{2}{*}{ Items } & \multicolumn{2}{|c|}{ IPI score } & \multicolumn{3}{|c|}{ AA stage } \\
\hline & $($ Mean \pm SD $)$ & P-value & $\mathrm{I} / \mathrm{II}$ & III/IV & P-value \\
\hline $\mathrm{CBC}^{\mathrm{a}}$ & & 0.046 & & & 0.005 \\
\hline $\mathrm{N}$ & $1.38 \pm 1.92$ & & 5 & 3 & \\
\hline $\mathrm{H}$ & $1.78 \pm 1.40$ & & 11 & 7 & \\
\hline $\mathrm{P}$ & $2.63 \pm 1.09$ & & 2 & 14 & \\
\hline LDH & & 0.001 & & & 0.020 \\
\hline High & $2.48 \pm 1.24$ & & 9 & 20 & \\
\hline Normal & $1.00 \pm 1.41$ & & 9 & 4 & \\
\hline Fever & & 0.022 & & & 0.024 \\
\hline Yes & $2.55 \pm 1.10$ & & 5 & 15 & \\
\hline No & $1.55 \pm 1.60$ & & 13 & 9 & \\
\hline CD5 & & 0.15 & & & 0.031 \\
\hline Positive & $1.86 \pm 1.51$ & & 15 & 14 & \\
\hline Negative & $2.58 \pm 1.16$ & & 2 & 10 & \\
\hline CD20 & & 0.95 & & & 0.084 \\
\hline Positive & $2.00 \pm 1.70$ & & 2 & 8 & \\
\hline Negative & $2.03 \pm 1.40$ & & 16 & 16 & \\
\hline
\end{tabular}

IPI, international prognostic index; AA, ann arbor; SD, standard deviation; CBC, complete blood count; N, normal, H, hemocytopenia; $\mathrm{P}$, pancytopenia; $\mathrm{LDH}$, lactate dehydrogenase. ${ }^{\mathrm{P}} \mathrm{P}=0.046$ for $\mathrm{CBC}-\mathrm{N}$ vs. $\mathrm{BCB}-\mathrm{P} ; \mathrm{P}=0.087$ for CBC-P vs. CBC-H; $\mathrm{P}=0.503$ for $\mathrm{CBC}-\mathrm{N}$ vs. $\mathrm{CBC}-\mathrm{H}$.

There was no significant difference in mean IPI score in the $\mathrm{CD}^{2} 0^{+} / \mathrm{CD} 20^{-}, \mathrm{CD}^{+} / \mathrm{CD}^{-}$and $\mathrm{CBC}$ groups (Tables I and III; Fig. 1).

Association of various factors with OS and mean survival time. The factors of gender, age, fever, LDH, CBC, AA stage, immunophenotyping (CD5/CD20) and IPI scores in relation to OS were analyzed using the Kaplan-Meier method. This analysis revealed that the OS rate was correlated with CD5 expression, CBC, LDH, AA stage and IPI score (Table IV and Fig. 2). Cox regression models were used to estimate the risk factors and adjust for potential confounding factors. CD5 ${ }^{-}$status $(\mathrm{P}=0.003)$, pancytopenia $(\mathrm{P}=0.003)$ and IPI scores $(\mathrm{P}=0.017)$ were found to be associated risk factors. In addition, statistical results indicated a longer mean survival time in the $\mathrm{CD}^{+}, \mathrm{CD} 20^{+}$and $\mathrm{CBC}-\mathrm{N}$ groups, and no significant difference was identified in survival time between patients with increased and normal LDH levels, or the groups with and without fever (Table IV).

\section{Discussion}

The clinical features of lymphoid neoplasms are diverse, and typical manifestations or pathological characteristics are lacking, which may delay diagnosis (15-18). With the implementation of new genomic sequencing strategies, the number of T/NK-cell lymphomas identified is likely to increase, particularly that of $\mathrm{EBV}^{+} \mathrm{T} / \mathrm{NK}$-cell neoplasms. The molecular pathogenesis is difficult to understand due to their complex and overlapping morphological and immunophenotypic characteristics (1). Such lymphomas have attracted an increasing amount of attention and consensus in regard to treatment $(6,7,14,19)$. However, as of yet, there is no standard staging system.

In the present study, it was found that the most common involved organ was the lymph node, followed by the skin and tissues of the digestive tract and respiratory tract, which might be associated with the routes of EBV infection and invasion. Generally, primary infected $B$ cells activate T cells and NK cells to recognize infected $B$ cells, which causes T/NK cell infection during clearance $(10,12,20-22)$. More than half the cases in the present study had multiple organ involvements, consistent with $\mathrm{EBV}^{+} \mathrm{T} / \mathrm{NK}$-cell neoplasms being highly aggressive and associated with poor prognosis. A previous study indicated that the exact mechanism by which EBV infects T/NK cells is associated with $\mathrm{CD}^{+} \mathrm{T}$ cells (20). In a previous study of lymphoma, the median age of all patients was $\sim 50$ years, and the male/female ratio was nearly 2 (23). In the present study, $\mathrm{EBV}^{+} \mathrm{T} / \mathrm{NK}$-cell neoplasms occurred at a younger median age (38 years), occurring preferentially in middle-aged men and young women.

Fever, asthenia, anorexia and jaundice associated with hepatosplenomegaly are the main clinical features of $\mathrm{T} / \mathrm{NK}$-cell neoplasms $(4,21)$. At present, malignancies are the most common causes of fever of undetermined origin in adults $(18-20,22)$. In the present study, almost half the patients had fever, which is possibly associated with inflammatory response syndrome induced by cytokines such as interleukin (IL)-1 $\beta$, IL-10, IL-13, IL-15 and tumor necrosis factor (TNF) (24). Previous studies have shown that the secretion of cytokines and chemotactic factors results in increases in EBV-LPDs (25), EBV latent membrane protein 1 induces 

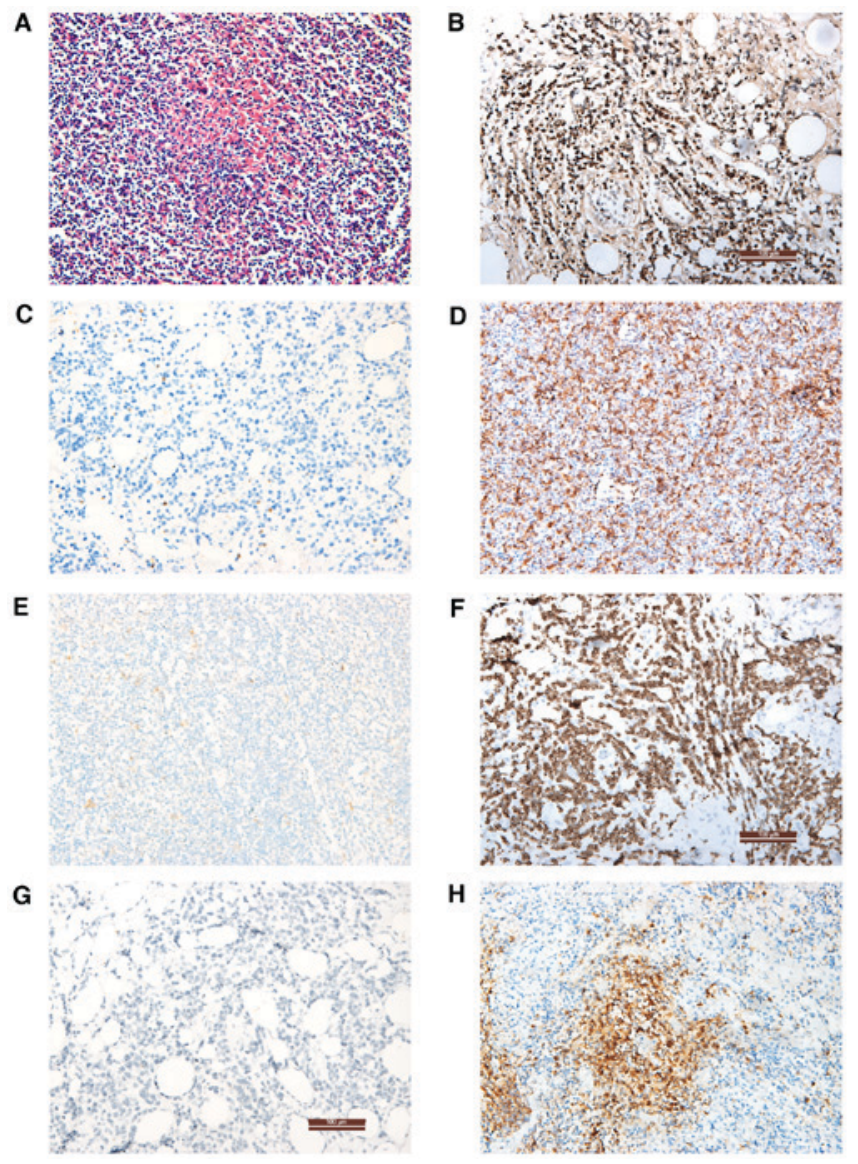

Figure 1. Pathological and immunohistochemical analysis of biopsy specimens. (A) Lymph node tissue with hematoxylin and eosin staining revealed loss of lymphatic structure, focal necrosis and active lymphocyte proliferation. (B) In situ hybridization showing an Epstein Barr virus-encoded $\mathrm{RNA}^{+}$result. Immunohistochemical staining showing (C) $\mathrm{CD}^{-}$, (D) $\mathrm{CD}^{+}$ (E) $\mathrm{CD} 3 \varepsilon^{-}$, (F) $\mathrm{CD}^{+} \varepsilon^{+},(\mathrm{G}) \mathrm{CD}^{-} 0^{-}$and $(\mathrm{H}) \mathrm{CD} 20^{+}$results. Magnification, x200.

Th1 factor secretion (e.g., TNF- $\alpha$ and interferon) via TNF receptor-associated factor and $\mathrm{NF}-\kappa \mathrm{B}$ in lymphoepithelioid lymphoma and T/NK LPDs, leading to cytokine storms, tissue damage and fever (24-26).

In the present study, there was no significant difference in IPI scores or AA stage between $\mathrm{CD} 20^{+}$and CD20- patients; however, CD20 expression was found to be associated with OS by Kaplan-Meier analysis, and the mean survival time in $\mathrm{CD} 20^{+}$patients was longer than that in $\mathrm{CD}_{20} 0^{-}$patients. A previous report suggested that $\mathrm{CD}_{2} 0^{+}$expression in $\mathrm{EBV}^{+} \mathrm{T} / \mathrm{NK}$ lymphoma indicates a better prognosis (27). Several studies concerning CD20 ${ }^{+}$or $\mathrm{CD} 7 \mathrm{a}^{+} \mathrm{T} / \mathrm{NK}$-cell lymphomas, or $\mathrm{CD}^{2} 9 \mathrm{a}^{+} \mathrm{CD} 20^{+} \mathrm{T}$-cell lymphomas have been conducted (27-29). CD20 ${ }^{+}$expression in $\mathrm{T} / \mathrm{NK}$ lymphoma confused the diagnosis. In the present study, one case with CD20 ${ }^{+}$expression was diagnosed among EBV-LPDs involving the $\mathrm{B}, \mathrm{T}$ and $\mathrm{NK}$ cell lines. It is possible that EBV-infected cells with dual expression are progenitor cells. Novel methods may be useful for diagnosis.

$\mathrm{CD}^{-}$status has been suggested to be an adverse prognostic factor (30), and the downregulation of CD5 expression in EBV-HLH has been reported to be associated with the serum levels of cytokines, and $\mathrm{T}$ cell activation and proliferation (31). In the present study, the IPI scores of CD5- patients
Table IV. Association of various factors with overall survival and mean survival time.

A, Association with overall survival

\begin{tabular}{lcc}
\hline Factor & Overall survival $\left(\chi^{2}\right)$ & P-value \\
\hline CD5 & 8.28 & 0.016 \\
CBC & 11.13 & 0.004 \\
LDH & 7.58 & 0.006 \\
CD20 & 2.07 & 0.150 \\
Gender & 1.098 & 0.295 \\
Fever & 1.318 & 0.251 \\
AA stage & 4.936 & 0.026 \\
Age groups & 1.934 & 0.380 \\
IPI scores & 15.68 & 0.003 \\
\hline
\end{tabular}

B, Association with mean survival time

\begin{tabular}{lcc}
\hline Factor & Survival time (months, mean \pm SD) & P-value \\
\hline CD5(+/-) & $16.90 \pm 10.89$ vs. $9.17 \pm 9.61$ & 0.039 \\
CD20(+/-) & $23.30 \pm 9.32$ vs. $11.59 \pm 10.04$ & 0.002 \\
LDH & $13.14 \pm 10.59$ vs. $17.15 \pm 11.80$ & 0.279 \\
(high/normal) & & \\
CBC (N/H/P) & $23.63 \pm 11.13$ vs. $14.39 \pm 10.16$ vs. & 0.011 \\
& $9.75 \pm 9.07$ &
\end{tabular}

CBC, complete blood count; LDH, lactate dehydrogenase; AA, Ann Arbor; IPI, International Prognostic Index; N, normal; H, hemocytopenia; $\mathrm{P}$, pancytopenia.

were clearly higher than those in $\mathrm{CD}^{+}$patients, and the mean survival time of $\mathrm{CD}^{-}$patients was shorter; moreover, an association between CD5 expression and OS was identified. Thus, $\mathrm{CD}^{-}$status could be considered to indicate poor prognosis and an aggressive clinical course for targeting with molecular therapy, comparable to MYC and BCL2 (32).

LDH reflects not only the tumor burden but also the host response. Increased LDH levels have been found to be associated with aggressiveness, resistance to chemotherapy and poor survival (33). Lu et al (34) used LDH-5 as a criterion in clinical trials for the stratification of patients with these malignancies. The upregulation of LDH in cancer cells is associated with the use of the glycolytic metabolism to meet energy requirements and reduce dependence on oxygen via the tricarboxylic acid cycle (35). LDH is regarded as a significant prognostic factor in diffuse large B cell lymphoma (36) and follicular lymphoma (37). In the present study, an increased LDH level indicated a low OS, which also indicates a poor prognosis in patients with T/NK-cell neoplasms.

Lymphoid neoplasms are heterogeneous, and 15-63\% of them involve the bone marrow during the later period of the disease (38). Thus, these neoplasms involve the peripheral blood or bone marrow, resulting in hypocytosis or pancytopenia. Abnormal CBCs were detected in $81 \%$ of patients in the present study, of which pancytopenia accounted for $40 \%$ 
A

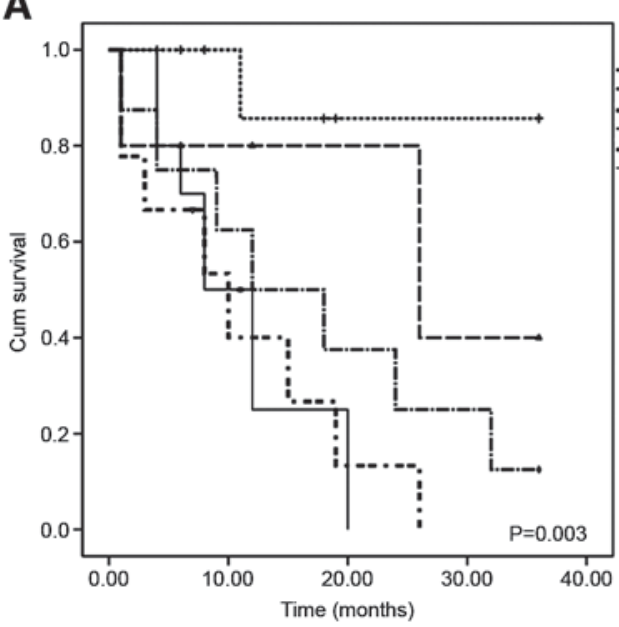

C

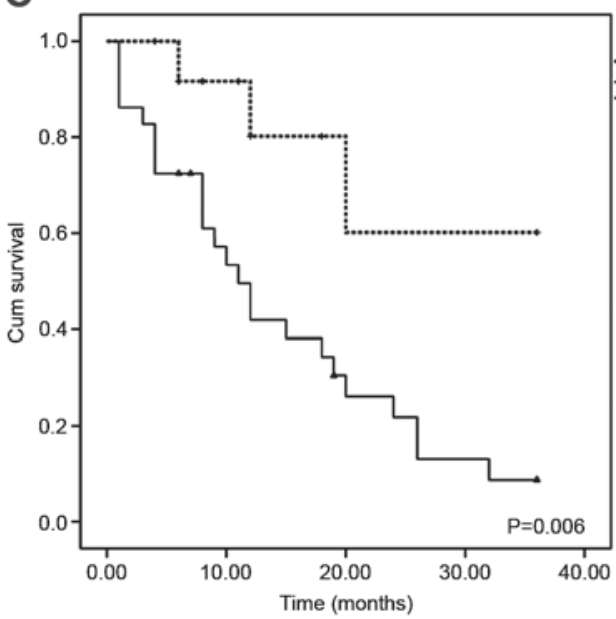

E

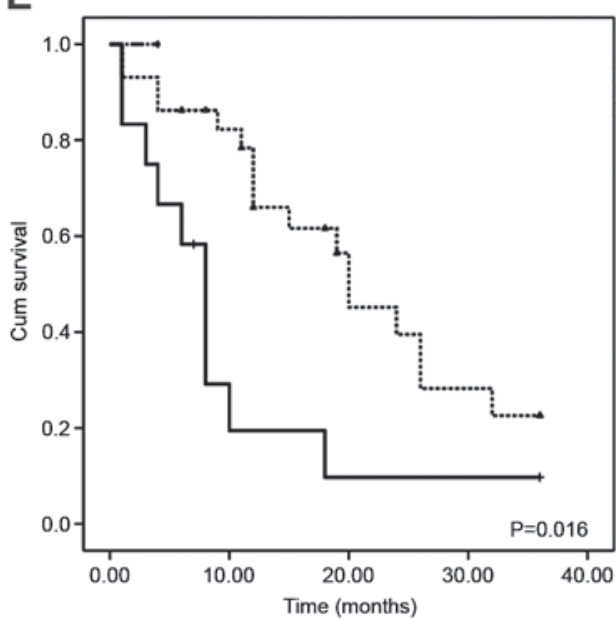

B
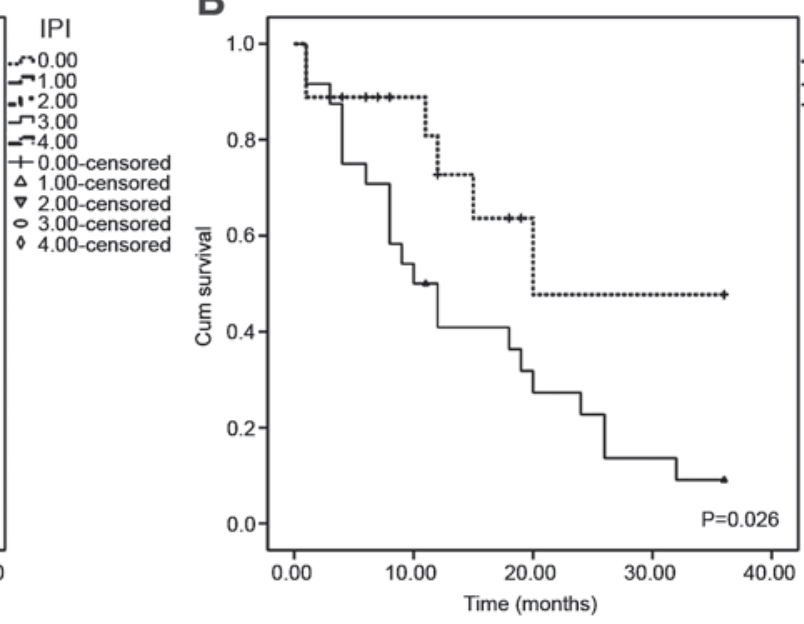

D

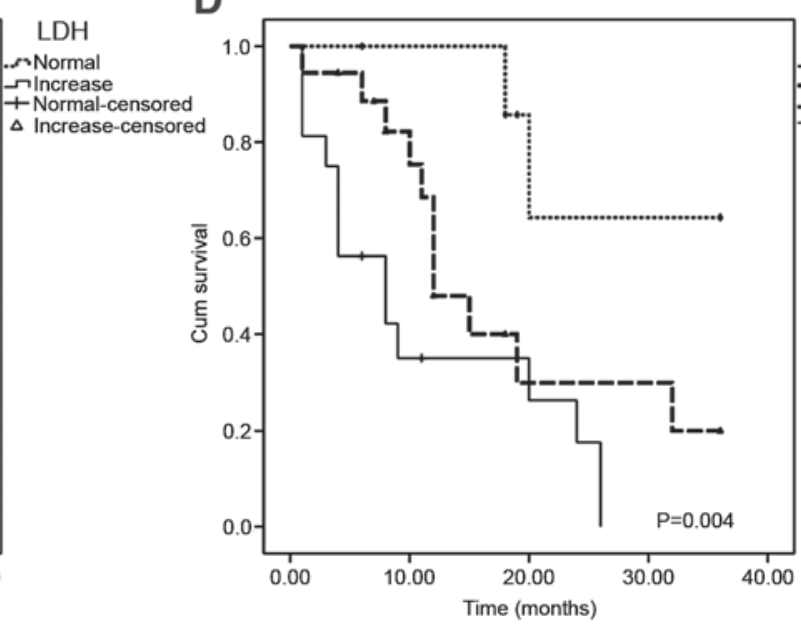

F

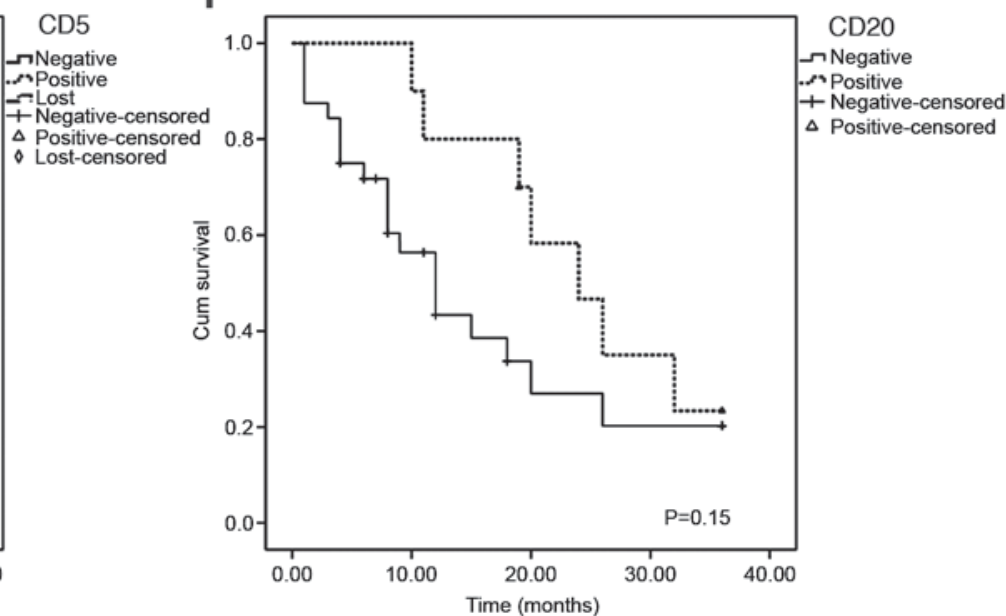

NI/II stage

+ I/II stage-censored

$\Delta$ III/IV stage-censored
CBC

$\sim$ Pancytopenia Hemocytopenia Norma ancytopenia-censored ytopenia-censored

Figure 2. Survival curves showing the association between factors and overall survival. Survival curves for (A) IPI scores, (B) AA stage, (C) LDH, (D) CBC, (E) CD5 and (F) CD20 and P-values are shown. IPI, International Prognostic Index; AA, Ann Arbor; LDH, lactate dehydrogenase; CBC, complete blood count.

and was associated with AA stage, IPI scores, OS and mean survival time, indicating that it is a prognostic factor.

In previous studies on T/NK-cell lymphoma, in patients who accepted chemotherapy alone, the 5-year OS rate of AA stage I/II was only $13-35 \%$. The majority of the patients who achieved complete remission by chemotherapy experienced relapse (39), although the recommended asparaginase (ASP)-containing regimens showed prominent activity against NK/T lymphoma (40,41). However, the efficacy of ASP-containing chemotherapies in improving OS remains unclear due to the lack of contemporaneous comparison. The high incidence of primary drug resistance in ENKL or ANKL may be due to the high expression of P-glycoprotein, a product of the multi-drug resistance gene, on neoplastic cells $(8,42)$. In the present study, the 3 -year OS was low $(17 \%)$. The possible causes are as follows: $\mathrm{EBV}^{+} \mathrm{T} / \mathrm{NK}$-cell 
neoplasms are highly aggressive, and ENKTL (nasal type) cases with comparatively better prognoses were excluded. A total of 10 cases were in follow-up; 4 were lost during chemotherapy.

The statistical analysis results indicated that the AA stage was an inferior factor with regard to OS and mean survival time in the present study. The AA staging system was originally designed for Hodgkin's lymphoma $(21,43)$ and was conventionally used for $\mathrm{EBV}^{+} \mathrm{T} / \mathrm{NK}$-cell neoplasms without considering the tumor size and invasion of contiguous structures. It has been suggested that the IPI score is not a perfect prognostic factor for NK/T lymphoma because of the lack of blood cell counts (44). The prognosis should be considered differently on the basis of different disease categories, such as the involved extranodal sites, LDH level, B symptoms, performance status, local tumor invasiveness, regional lymph node metastasis and pretreatment plasma EBV-DNA quantities (45) representing tumor burden.

The definitions and terminology, particularly for $\mathrm{EBV}^{+}$ T/NK-cell neoplasms in adults, remain controversial. The diagnosis and treatment protocols are complicated. Thus, it may be necessary to design an appropriate staging system to effectively stratify tumor burden and survival risk and thus guide treatment decisions. Fever and CBC may be regarded as a complement to IPI scores and AA staging. The results of the present study indicated an association of CD5 and CD20 with prognosis. Efforts to identify pathological predictors of prognosis and potential therapeutic targets in different categories are recommended.

\section{Acknowledgements}

The authors thank American Journal Experts (Durham, NS, USA) for English language editing. The authors are grateful to the Pathology Department of Xiangya Hospital for kindly assisting with immunohistochemistry experiment and to the Clinical Laboratory of Xiangya Hospital for the assistance with $\mathrm{CBC}$ and LDH examination.

\section{References}

1. Campo E, Swerdlow SH, Harris NL, Pileri S, Stein H and Jaffe ES: The 2008 WHO classification of lymphoid neoplasms and beyond: Evolving concepts and practical applications. Blood 117: 5019-5032, 2011.

2. Vose J, Armitage J and Weisenburger D; International T-Cell Lymphoma Project: International peripheral T-cell and natural killer/T-cell lymphoma study: Pathology findings and clinical outcomes. J Clin Oncol 26: 4124-4130, 2008.

3. Mitrovic Z, Perry AM, Suzumiya J, Armitage JO, Au WY, Coiffier B, Holte H, Jaffe ES, Monserrat E, Rajan SK, et al: The prognostic significance of lymphopenia in peripheral T-cel and natural killer/T-cell lymphomas: A study of 826 cases from the International Peripheral T-cell Lymphoma Project. Am J Hematol 87: 790-794, 2012.

4. Jo JC, Yoon DH, Kim S, Lee BJ, Jang YJ, Park CS, Huh J, Lee SW, Ryu JS and Suh C: Clinical features and prognostic model for extranasal NK/T-cell lymphoma. Eur J Haematol 89 : 103-110, 2012.

5. Ko YH, Ree HJ, Kim WS, Choi WH, Moon WS and Kim SW: Clinicopathologic and genotypic study of extranodal nasal-type natural killer/T-cell lymphoma and natural killer precursor lymphoma among Koreans. Cancer 89: 2106-2116, 2000.

6. Suzuki R: NK/T-cell lymphomas: Pathobiology, prognosis and treatment paradigm. Curr Oncol Rep 14: 395-402, 2012.

7. Kawa K: Epstein-Barr virus-associated diseases in humans. Int J Hematol 71: 108-117, 2000.
8. Oshimi K: Progress in understanding and managing natural killer-cell malignancies. Br J Haematol 139: 532-544, 2007.

9. Park S and Ko YH: Epstein-Barr virus-associated T/natural killer-cell lymphoproliferative disorders. J Dermatol 41: 29-39, 2014.

10. Garady C, Saieg MA, Ko HM, Geddie WR, Boerner SL and da Cunha Santos G: Epstein-Barr virus encoded RNA detected by in situ hybridization using cytological preparations. Cytopathology 25: 101-107, 2014

11. Swerdlow SH, Campo E, Pileri SA, Harris NL, Stein H, Siebert R, Advani R, Ghielmini M, Salles GA, Zelenetz AD and Jaffe ES: The 2016 revision of the world health organization classification of lymphoid neoplasms. Blood 127: 2375-2390, 2016.

12. Zelenetz AD, Gordon LI, Wierda WG, Abramson JS, Advani RH, Andreadis CB, Bartlett N, Bellam N, Byrd JC, Czuczman MS, et al: Non-Hodgkin's lymphomas, version 2.2014. J Natl Compr Canc Netw 12: 916-946, 2014.

13. International Non-Hodgkin's Lymphoma Prognostic Factors Project: A predictive model for aggressive Non-Hodgkin's lymphoma. N Engl J Med 329: 987-994, 1993.

14. Kwong YL, Pang AW, Leung AY, Chim CS and Tse E: Quantification of circulating Epstein-Barr virus DNA in NK/T-cell lymphoma treated with the SMILE protocol: Diagnostic and prognostic significance. Leukemia 28: 865-870, 2014.

15. Hong J, Park S, Baek HL, Jung JH, Kang IG, Sym SJ, Park J, Ahn JY, Cho EK, Kim ST, et al: Tumor cell nuclear diameter and CD30 expression as potential prognostic parameter in patients with extranodal NK/T-cell lymphoma, nasal type. Int J Clin Exp Pathol 5: 939-947, 2012

16. Krenacs L, Smyth MJ, Bagdi E, Krenacs T, Kopper L, Rudiger T, Zettl A, Muller-Hermelink HK, Jaffe ES and Raffeld M: The serine protease granzyme $\mathrm{M}$ is preferentially expressed in NK-cell, gamma delta T-cell, and intestinal T-cell lymphomas: Evidence of origin from lymphocytes involved in innate immunity. Blood 101: 3590-3593, 2003.

17. Taylor GS, Long HM, Brooks JM, Rickinson AB and Hislop AD: The immunology of Epstein-Barr virus-induced disease. Annu Rev Immunol 33: 787-821, 2015.

18. Bajor-Dattilo EB, Pittaluga S and Jaffe ES: Pathobiology of T-cell and NK-cell lymphomas. Best Pract Res Clin Haematol 26: 75-87, 2013.

19. Cai Q, Chen K and Young KH: Epstein-Barr virus-positive T/NK-cell lymphoproliferative disorders. Exp Mol Med 47: e133, 2015.

20. Yuling H, Ruijing X, Li L, Xiang J, Rui Z, Yujuan W, Lijun Z, Chunxian D, Xinti T, Wei X, et al: EBV-induced human CD8+ NKT cells suppress tumorigenesis by EBV-associated malignancies. Cancer Res 69: 7935-7944, 2009.

21. Wang RC, Chang ST, Hsieh YC, Huang WT, Hsu JD, Tseng CE, Wang MC, Hwang WS, Wang J and Chuang SS: Spectrum of Epstein-Barr virus-associated T-cell lymphoproliferative disorder in adolescents and young adults in Taiwan. Int J Clin Exp Pathol 7: 2430-2437, 2014.

22. Liaw CC, Chen JS, Wang CH, Chang HK and Huang JS: Tumor fever in patients with nasopharyngeal carcinoma: Clinical experience of 67 patients. Am J Clin Oncol 21: 422-425, 1998.

23. Kim TM, Park YH, Lee SY, Kim JH, Kim DW, Im SA, Kim TY, Kim CW, Heo DS, Bang YJ, et al: Local tumor invasiveness is more predictive of survival than international prognostic index in stage $\mathrm{I}(\mathrm{E}) / \mathrm{II}(\mathrm{E})$ extranodal NK/T-cell lymphoma, nasal type. Blood 106: 3785-3790, 2005.

24. Mazodier K, Marin V, Novick D, Farnarier C, Robitail S, Schleinitz N, Veit V, Paul P, Rubinstein M, Dinarello CA, et al: Severe imbalance of IL-18/IL-18BP in patients with secondary hemophagocytic syndrome. Blood 106: 3483-3489, 2005.

25. Kimura H, Hoshino Y, Hara S, Sugaya N, Kawada J, Shibata Y, Kojima S, Nagasaka T, Kuzushima K and Morishima T: Differences between T cell-type and natural killer cell-type chronic active Epstein-Barr virus infection. J Infect Dis 191: 531-539, 2005.

26. Chuang HC, Lay JD, Chuang SE, Hsieh WC, Chang Y and Su IJ: Epstein-Barr virus (EBV) latent membrane protein-1 down-regulates tumor necrosis factor-alpha (TNF-alpha) receptor-1 and confers resistance to TNF-alpha-induced apoptosis in T cells: Implication for the progression to T-cell lymphoma in EBV-associated hemophagocytic syndrome. Am J Pathol 170: 1607-1617, 2007.

27. Jiang QP, Liu SY, Yang YX, Tan XX, Peng J, Xiong ZT and Li Z: CD20-positive NK/T-cell lymphoma with indolent clinical course: Report of case and review of literature. Diagn Pathol 7: 133,2012 
28. Gill HS, Lau WH, Chan AC, Leung RY, Khong PL, Leung AY and Kwong YL: CD20 expression in natural killer T cell lymphoma. Histopathology 57: 157-159, 2010.

29. Huang YH, Huang CT, Tan SY and Chuang SS: Primary gastric extranodal natural killer/T-cell lymphoma, nasal type, with acquisition of CD20 expression in the subcutaneous relapse: Report of a case with literature review. J Clin Pathol 68: 943-945, 2015.

30. Chuang WY, Chang H, Shih LY, Wang PN, Chang YS, Lin TL, Hung YS, Yeh CJ, Ueng SH, Tang TC, et al: CD5 positivity is an independent adverse prognostic factor in elderly patients with diffuse large B cell lymphoma. Virchows Arch 467: 571-582, 2015.

31. Wada T, Sakakibara Y, Nishimura R, Toma T, Ueno Y, Horita S, Tanaka T, Nishi M, Kato K, Yasumi T, et al: Down-regulation of CD5 expression on activated CD8+ T cells in familial hemophagocytic lymphohistiocytosis with perforin gene mutations. Hum Immunol 74: 1579-1585, 2013.

32. Karsan A, Gascoyne RD, Coupland RW, Shepherd JD, Phillips GL and Horsman DE: Combination of $\mathrm{t}(14 ; 18)$ and a Burkitt's type translocation in B-cell malignancies. Leuk Lymphoma 10: 433-441, 1993

33. Adida C, Haioun C, Gaulard P, Lepage E, Morel P, Briere J, Dombret H, Reyes F, Diebold J, Gisselbrecht C, et al: Prognostic significance of survivin expression in diffuse large B-cell lymphomas. Blood 96: 1921-1925, 2000.

34. Lu R, Jiang M, Chen Z, Xu X, Hu H, Zhao X, Gao X and Guo L: Lactate dehydrogenase 5 expression in Non-Hodgkin lymphoma is associated with the induced hypoxia regulated protein and poor prognosis. PLoS One 8: e74853, 2013.

35. Serganova I, Rizwan A, Ni X, Thakur SB, Vider J, Russell J, Blasberg R and Koutcher JA: Metabolic imaging: A link between lactate dehydrogenase A, lactate, and tumor phenotype. Clin Cancer Res 17: 6250-6261, 2011.

36. Sehn LH, Berry B, Chhanabhai M, Fitzgerald C, Gill K, Hoskins P, Klasa R, Savage KJ, Shenkier T, Sutherland J, et al: The revised international prognostic index (R-IPI) is a better predictor of outcome than the standard IPI for patients with diffuse large B-cell lymphoma treated with R-CHOP. Blood 109: 1857-1861, 2007.

37. Buske C, Hoster E, Dreyling M, Hasford J, Unterhalt M and Hiddemann W: The follicular lymphoma international prognostic index (FLIPI) separates high-risk from intermediate- or low-risk patients with advanced-stage follicular lymphoma treated front-line with rituximab and the combination of cyclophosphamide, doxorubicin, vincristine, and prednisone (R-CHOP) with respect to treatment outcome. Blood 108: 1504-1508, 2006.
38. Tomita N, Taguri M, Hashimoto C, Takasaki H, Fujimaki K, Motomura S, Koharazawa H, Takemura S, Fujita H, Yamazaki E, et al: Evaluation of soluble interleukin-2 receptor and serum lactate dehydrogenase in malignant lymphoma. Ann Hematol 94: 1935-1937, 2015.

39. Chauchet A, Michallet AS, Berger F, Bedgedjian I, Deconinck E, Sebban C, Antal D, Orfeuvre H, Corront B, Petrella T, et al: Complete remission after first-line radio-chemotherapy as predictor of survival in extranodal NK/T cell lymphoma. J Hematol Oncol 5: 27, 2012.

40. Dearden CE, Johnson R, Pettengell R, Devereux S, Cwynarski K, Whittaker S and McMillan A; British and Committee for Standards in Haematology: Guidelines for the management of mature T-cell and NK-cell neoplasms (excluding cutaneous T-cell lymphoma). Br J Haematol 153: 451-485, 2011.

41. Zelenetz AD, Abramson JS, Advani RH, Andreadis CB, Byrd JC, Czuczman MS, Fayad L, Forero A, Glenn MJ, Gockerman JP, et al: NCCN clinical practice guidelines in oncology: Non-Hodgkin's lymphomas. J Natl Compr Canc Netw 8: 288-334, 2010.

42. Kwong YL: Natural killer-cell malignancies: Diagnosis and treatment. Leukemia 19: 2186-2194, 2005.

43. Cheung MM, Chan JK and Wong KF: Natural killer cell neoplasms: A distinctive group of highly aggressive lymphomas/leukemias. Semin Hematol 40: 221-232, 2003.

44. Federico M, Rudiger T, Bellei M, Nathwani BN, Luminari S, Coiffier B, Harris NL, Jaffe ES, Pileri SA, Savage KJ, et al: Clinicopathologic characteristics of angioimmunoblastic T-Cell lymphoma: Analysis of the international peripheral T-cell lymphoma project. J Clin Oncol 31: 240-246, 2013.

45. Wang ZY, Liu QF, Wang H, Jin J, Wang WH, Wang SL, Song YW, Liu YP, Fang H, Ren H, et al: Clinical implications of plasma Epstein-Barr virus DNA in early-stage extranodal nasal-type NK/T-cell lymphoma patients receiving primary radiotherapy. Blood 120: 2003-2010, 2012 